\title{
Comparison of indigenous and selected mycorrhiza in terms of growth increases and mycorrhizal dependency of sour orange under phosphorus and zinc deficient soils
}

I. Ortas

Department of Soil Science and Plant Nutrition, University of Çukurova, Faculty of Agriculture, Adana, Turkey

\section{Summary}

The soils of Central Anatolia contain a high clay content, pH and low fertility, especially zinc (Zn) and phosphorus (P) levels, and this region also experiences less precipitation; consequently, crop production is primarily limited due to $\mathrm{Zn}$ and $\mathrm{P}$ deficiency. The objective of this study was to evaluate the effects of inoculating selected single arbuscular mycorrhizae (AM) and indigenous native mycorrhizae (INM), along with the application of $P$ and $\mathrm{Zn}$ doses, on the growth and nutrient uptake of sour orange (Citrus aurantium L.) seedlings under sterile soil conditions. Our hypothesis was that citrus growth is dependent on AM fungi in terms of $P$ and $Z n$ nutrition. A fully factorial experiment was set up to test the effects of mycorrhizal fungi, $\mathrm{P}$ and $\mathrm{Zn}$ doses, and two soils on the growth and nutrient uptake of sour orange under greenhouse conditions.

In both soils, mycorrhizal inoculation increased certain growth parameters of citrus seedlings, such as shoot height, shoot and root dry matter, and root infection. Generally, mycorrhizae-inoculated seedlings grew better than the control plants; however, mycorrhizal inoculation also significantly increased plant tissue $\mathrm{Zn}$ and $\mathrm{P}$ uptake. In the absence of mycorrhizal inoculation, shoot and root dry matter production were severely affected by the application of $P$ and $Z n$, and supplying adequate amounts of $P$ and Zn significantly increased plant growth parameters. Under low $P$ addition, Rhizoglomus clarum-inoculated plants exhibited an increased $P$ concentration, up to $83 \%$, and an up to $54 \%$ increase of $\mathrm{Zn}$ concentration. Under a high $P$ level application, the increase of $P$ and $\mathrm{Zn}$ concentration decreased. Inoculated citrus seedlings had high mycorrhizae dependency, which was significantly affected by the soil series and $P$, and only partially by $\mathrm{Zn}$ application. The results indicate that INM inoculation is as effective as $R$. clarum inoculation.

Keywords

sour orange, indigenous mycorrhiza, mycorrhizal dependency, P and Zn uptake

\section{Introduction}

Zinc (Zn) and phosphorus (P) deficiency are common soil nutritional problems in the Central Anatolia region of Turkey (Ortas and Coskan, 2016). Zn deficiency significantly restricts the yield (Ortas, 2017) of many arable plants and Zn-sensi-

\section{Significance of this study}

What is already known on this subject?

- In this work we investigate the effect of indigenous and selected mycorrhiza on growth and mycorrhizal dependency of sour orange under phosphorus and zinc deficient soil conditions.

What are the new findings?

- We found that indigenous mycorrhiza inoculum is as effective as selected $R$. clarum inoculation. Also mycorrhiza inoculation increased nutrient concentration of citrus seedling.

What is the expected impact on horticulture?

- Mycorrhiza has a great importance for sustainable agriculture, which enhances the growth of citrus plants/sour orange, especially in the soils with $\mathrm{P}$ and $\mathrm{Zn}$ deficiency. The results are strongly suggesting that under $\mathrm{P}$ and $\mathrm{Zn}$ deficiency soil conditions, mycorrhizal inoculation is necessary for better plant growth.

tive plant species cannot grow properly; therefore, in order to produce sufficient yield, farmers need to use $\mathrm{Zn}$ fertilizers. In addition, irrigated areas require high levels of $\mathrm{P}$ fertilizer. Since chemical fertilizer sources, especially $\mathrm{Zn}$ and $\mathrm{P}$, are expensive and have a negative influence on the soil quality, it is reasonable to use and/or manage rhizosphere mechanisms such as mycorrhizae fungi. Arbuscular mycorrhizal (AM) symbiosis is one of the largest symbioses between plant root and fungi. Mycorrhizae play a key role in nutrient uptake (Ortas, 2012b; Ortas and Ustuner, 2014b; Wu et al., 2017a) and increase plant resistance against external stress factors (Wu et al., 2013). AMF as a biostimulant has a significant effect on plant health, and the nutrition and quality of horticultural crops (Rouphael et al., 2015). The results of Satir et al. (2016) showed that selected and indigenous mycorrhizae, especially spores extracted from the rhizospheres of different plant species, had a significant effect on citrus growth and nutrient uptake.

Citrus plants are extremely sensitive to $\mathrm{Zn}$ deficiency. As citrus plants have coarse root systems, in order to obtain sufficient nutrients and water they mainly form symbiotic associations with AMF (Nunes et al., 2006; Ortas, 2012b); hence, citrus plants are obligatorily mycorrhizal dependent (Nunes et al., 2006; Ortas and Ustuner, 2014a, b; Ortas and Varma, 2007). Citrus plants obtain maximum benefit from mycorrhiza (Al-Karaki, 2013; Li et al., 2013; Ortas, 2012b; Wu et al., 2011), in particular, a high P, Zn uptake (Navarro and Morte, 
2019; Ortas et al., 2016) and Mg and Fe as well. Exotic and/or indigenous native mycorrhizae (INM) in soil is a critical factor in citrus seedling growth in the presence of a low supply of $\mathrm{P}$ and $\mathrm{Zn}$ (Ortas et al., 2016).

Our previous results indicated that there was a great variation in mycorrhizal colonization, dependent upon soil and plant properties (Ortas et al., 2018). Usually, many plant species are mycorrhizal dependent (MD) in terms of $\mathrm{P}$ nutrition. Since citrus plants obtain mycorrhizal benefit via $\mathrm{Zn}$ nutrition, MD may also be affected by Zn nutrition. Mycorrhizal dependencies are higher when citrus plants are grown in low-P soils than in high P nutrient levels. However, very little work has been conducted on the mycorrhizal dependence of $\mathrm{Zn}$ application on root colonization or the relationship between $\mathrm{Zn}$ nutrition and mycorrhizal dependency. It is well known that citrus plants are strongly mycorrhizal dependent on $\mathrm{P}$ nutrition, but less is known about the mycorrhizal dependence on Zn nutrition (Ortas, 2012a). In the present study we attempted to investigate the role of mycorrhizal inoculation on the growth of citrus seedlings in two calcareous Central Anatolian soils both of which had a low Zn and P concentration. Also indigenous mycorrhiza was compared with selected mycorrhizae species in terms of growth and mycorrhizae dependency. Thus, the tested hypothesis was that citrus plant growth is dependent upon AM fungi in terms of $\mathrm{P}$ and $\mathrm{Zn}$ nutrition. The objective of this study was to evaluate the effects of inoculating selected single arbuscular mycorrhiza (AM) and indigenous native mycorrhizae (INM), along with the application of $\mathrm{P}$ and $\mathrm{Zn}$ doses, on the growth and nutrient uptake of sour orange (Citrus aurantium L.) seedlings.

\section{Materials and methods}

\section{Soil properties and experimental design}

Experiments were conducted under greenhouse conditions using two P and $\mathrm{Zn}$ low fertile calcareous Central Anatolia (Sultanönü and Konya) soils for a duration of 8 months. Certain physical and chemical properties of the soils are presented in Table 1.

Soils were sterilized for $2 \mathrm{~h}$ at $120^{\circ} \mathrm{C}$ in an autoclave, and citrus seedlings were grown for 8 months under greenhouse conditions at two levels of $\mathrm{P}\left(\mathrm{P} 0=0, \mathrm{P} 1=100 \mathrm{mg} \mathrm{P} \mathrm{kg}^{-1}\right.$ soil $)$, three levels of $\mathrm{Zn}\left(\mathrm{Zn} 0=0, \mathrm{Zn} 1=5\right.$ and $\mathrm{Zn} 2=10 \mathrm{mg} \mathrm{Zn} \mathrm{kg}^{-1}$ soil) in $3 \mathrm{~kg}$ of soil per pot. The soils were also treated with $200 \mathrm{mg} \mathrm{N} \mathrm{kg}^{-1}$ soil $\left[100 \mathrm{mg} \mathrm{kg}^{-1} \text { soil N-( } \mathrm{NH}_{4}\right)_{2} \mathrm{SO}_{4}, 100 \mathrm{mg} \mathrm{kg}^{-1}$ soil $\mathrm{N}-\mathrm{KNO}_{3}$ ] and $10 \mathrm{mg} \mathrm{kg}^{-1}$ soil Fe (Fe-EDDHA) was applied.

Rhizoglomus clarum (T.H. Nicolson \& N.C. Schenck) and indigenous native mycorrhiza (collected from citrus orchard) were used as the arbuscular mycorrhizal fungi at a concentration of 500 spores; mycorrhizae spores were applied $5 \mathrm{~cm}$ below the plantlets. Non-inoculated plantlets received the same amount of non-mycorrhizal inoculum including growth media and plant roots.

\section{Seedling production}

Sour orange (Citrus aurantium L.) seeds were surface sterilized with a sodium hypochlorite solution ( $2 \%$ of available chlorine) for 5 minutes, and rinsed and then soaked in distilled water 4 times. Seeds were sown for 6 weeks in a 6:3:1 torfe perlite and soil growth medium under controlled glasshouse conditions; when the seedlings grew to a 3-leaf stage they were transplanted into 3 -kg plastic pots.

\section{Mycorrhizal colonization (\%)}

Seedlings were harvested when they were 8 months old. After harvest, plant roots were separated and washed several times with de-ionized water; excess water was removed by drying on tissue paper. Sub samples of roots were stained as described by Koske and Gemma (1989), and mycorrhizal colonization was determined by the method of Giovannetti and Mosse (1980).

After drying the seedling leaves, they were ground, ashed and the $\mathrm{P}$ concentrations of the ash solution were determined by the Murphy and Riley (1962) method, and Zn concentration was determined using a spectrophotometer and atomic absorption spectrophotometer.

Mycorrhizal dependency (MD) was determined by expressing the difference between the dry weight of the mycorrhizal plant (MP) and the dry weight (DW) of the non-mycorrhizal plant (NMP) as a percentage of the dry weight of the mycorrhizal plant (Plenchette et al., 1983).

TABLE 1. Selected physical, chemical and biological properties of soils.

\begin{tabular}{|c|c|c|c|}
\hline Properties & Unit & Sultanönü & Konya \\
\hline Clay & \multirow{6}{*}{$\%$} & 50.6 & 44.6 \\
\hline Loam & & 30.6 & 40.4 \\
\hline Sand & & 18.8 & 15.0 \\
\hline $\mathrm{CaCO}_{3}$ & & 15 & 32 \\
\hline Organic matter & & 0.7 & 1.2 \\
\hline Salt (soluble) & & 0.08 & 0.06 \\
\hline$B^{(1)}$ & $\mathrm{mg} \mathrm{B} \mathrm{kg}^{-1}$ soil & 1.2 & 23.7 \\
\hline $\mathrm{pH}$ & $\mathrm{H}_{2} \mathrm{O}$ & 8.04 & 8.01 \\
\hline CEC (4) & $\mathrm{Cmol}_{\mathrm{c}} \mathrm{kg}^{-1}$ & 38 & 26 \\
\hline $\mathrm{P}_{2} \mathrm{O}_{5}(2)$ & $\mathrm{kg} \mathrm{ha}^{-1}$ & 40.37 & 30.28 \\
\hline $\mathrm{Zn}{ }^{(3)}$ & \multirow{4}{*}{$\mathrm{mg}^{-1} \mathrm{~kg}$} & 0.19 & 0.15 \\
\hline $\mathrm{Fe}^{(3)}$ & & 2.64 & 2.03 \\
\hline $\mathrm{Mn}(3)$ & & 2.13 & 4.68 \\
\hline $\mathrm{Cu}^{(3)}$ & & 0.95 & 0.42 \\
\hline Indigenous mycorrhizae & Spores number $10 \mathrm{~g}^{-1}$ dry soil & 57 & 39 \\
\hline
\end{tabular}

(1) $\mathrm{CaCO}_{2} /$ Mannitol; (2) $0.5 \mathrm{~N} \mathrm{NaHCO}_{3}$ extractable; (3) DTPA extractable; (4) CEC: Cation Exchange Capacity.

Values are the averages of three samples. 


$$
\mathrm{MD}=\frac{\mathrm{DW} \text { of MP }-\mathrm{DW} \text { of NMP }}{\mathrm{DW} \text { of MP }} \times 100
$$

\section{Percentage nutrient increase (NIP) in the presence of arbuscular mycorrhiza fungi}

The percentage increase of citrus shoot $\mathrm{P}$ and $\mathrm{Zn}$ concentration in the presence of AMF (AMF-nutrient, \%) was calculated using a similar formula for mycorrhizae dependency:

$$
\mathrm{NIP}=\frac{\mathrm{NC} \text { of MP }-\mathrm{NC} \text { of NMP }}{\mathrm{NC} \text { of MP }} \times 100
$$

where nutrient concentration (NC) and NC-AMF are the shoot $\mathrm{P}$ concentrations of sour orange with and without $\mathrm{AMF}$ inoculation, respectively.

\section{Statistical analysis}

All plant parameters were assessed via the analysis of variance ANOVA procedure using the Statistical Analysis System (SAS) 9.3 packet program. The main significant interactive effects of treatments were separated using the Tukey test at $\mathrm{P}<0.05$.

\section{Results and discussion}

\section{Root colonization}

Under both soil conditions, mycorrhizal inoculation significantly increased the percentage (\%) root colonization (Table 2). In general, $R$. clarum-inoculated plants exhibited higher root colonization than those inoculated with INM. For the Sultanönü soil, in control plants the root colonization ranged between 0 to $1 \%$; however, for the $R$. clarum-inoculated plants the root colonization ranged from 40 to $63 \%$ and for INM-inoculated plants the root colonization ranged from 40 to $46.7 \%$. In the Konya soil, without mycorrhizal inoculation, the root colonization ranged from 0 to $2 \%$; however, for the $R$. clarum inoculation, the root colonization ranged from 51 to $69 \%$ and for INM-inoculated plants, the root colonization ranged from 26.7 to $30 \%$.

As can be seen in Table 2, for both soils, re-inoculation of an INM-inoculated plant root resulted in higher colonization. In these experiments, indigenous mycorrhizae were cultured using a trap culture and re-used, which is very important for the effectiveness of indigenous mycorrhizae. Previously $\mathrm{Wu}$ et al. (2017b) reported that since soil have native mycorrhizal fungi they mostly colonized the citrus roots. In addition, it is important to manage the indigenous inoculum of each plant rhizosphere mycorrhiza. In our previous work (Ortas, 2008, 2012b; Ortas and Ustuner, 2014a, b), we found that if indigenous mycorrhiza multiply correctly they are as efficient as exotic mycorrhizae species. Since citrus plants are highly dependent on mycorrhizal colonization, using even a small inoculum can cause a good response. For both soils and inoculations, increasing the $\mathrm{P}$ addition slightly reduced root colonization and it is well known that increasing the P fertilizer level reduces colonization (Wu et al., 2006). Nunes et al. (2006) reported that citrus roots exhibit a high response to mycorrhizal colonization even under high soil P conditions.

In the present study, for both soils, increasing the P addition had no significant effect on root colonization. However, in the Sultanönü soil, increasing the rate of $\mathrm{Zn}$ addition led to a statistically significantly effect on root colonization, indicating that soil ecological parameters have an effect on root colonization.
TABLE 2. Effect of $R$. clarum and indigenous mycorrhizal inoculation. $\mathrm{P}\left(\mathrm{mg} \mathrm{kg}^{-1} \mathrm{P}_{2} \mathrm{O}_{5}\right)$ and $\mathrm{Zn}\left(\mathrm{mg} \mathrm{kg}^{-1}\right)$ application on sour orange seedlings root colonization (\%).

\begin{tabular}{lccc}
\hline Mycorrhizae & Treatment & Sultanönü & Konya \\
\hline Control & ZnOP0 & $1.00 \pm 1.73 \mathrm{e}$ & $0.00 \pm 0.00 \mathrm{~d}$ \\
& Zn1P0 & $0.00 \pm 0.00 \mathrm{e}$ & $0.00 \pm 0.00 \mathrm{~d}$ \\
& Zn2P0 & $1.00 \pm 1.73 \mathrm{e}$ & $1.00 \pm 1.73 \mathrm{~d}$ \\
& Zn0P1 & $0.00 \pm 0.00 \mathrm{e}$ & $0.00 \pm 0.00 \mathrm{~d}$ \\
& Zn1P1 & $1.00 \pm 1.73 \mathrm{e}$ & $2.00 \pm 1.73 \mathrm{~d}$ \\
& Zn2P1 & $1.00 \pm 1.73 \mathrm{e}$ & $1.00 \pm 1.73 \mathrm{~d}$ \\
\hline R. clarum & Zn0P0 & $60.00 \pm 10.00 \mathrm{ab}$ & $65.00 \pm 5.00 \mathrm{a}$ \\
& Zn1P0 & $63.33 \pm 5.77 \mathrm{a}$ & $69.33 \pm 8.08 \mathrm{a}$ \\
& Zn2P0 & $58.00 \pm 3.46 \mathrm{a}-\mathrm{c}$ & $58.33 \pm 9.71 \mathrm{ab}$ \\
& Zn0P1 & $51.33 \pm 2.31 \mathrm{~b}-\mathrm{d}$ & $43.33 \pm 15.28 \mathrm{bc}$ \\
& Zn1P1 & $40.00 \pm 10.00 \mathrm{~d}$ & $55.33 \pm 5.03 \mathrm{ab}$ \\
& Zn2P1 & $43.33 \pm 5.77 \mathrm{~d}$ & $51.67 \pm 7.64 \mathrm{ab}$ \\
\hline Indigenous & Zn0P0 & $40.00 \pm 10.00 \mathrm{~d}$ & $30.00 \pm 17.32 \mathrm{c}$ \\
mycorrhizae & Zn1P0 & $46.67 \pm 5.77 \mathrm{~cd}$ & $30.00 \pm 20.00 \mathrm{c}$ \\
& Zn2P0 & $43.33 \pm 11.55 \mathrm{~d}$ & $26.67 \pm 15.28 \mathrm{c}$ \\
& Zn0P1 & $43.33 \pm 5.77 \mathrm{~d}$ & $26.67 \pm 20.82 \mathrm{c}$ \\
& Zn1P1 & $40.00 \pm 10.00 \mathrm{~d}$ & $30.00 \pm 17.32 \mathrm{c}$ \\
& Zn2P1 & $40.00 \pm 10.00 \mathrm{~d}$ & $30.00 \pm 10.00 \mathrm{c}$ \\
\hline
\end{tabular}

Mean (three replicates) is SE (Standard error).

Columns with different letters are significantly different $(P<0.05)$ according to LSD test.

\section{Plant growth parameters}

In both Sultanönü and Konya soils, mycorrhizal inoculation, the rate of $\mathrm{P}$ and $\mathrm{Zn}$ addition significantly increased the growth of citrus seedlings. The height of the citrus seedlings was greatly affected by mycorrhizal treatment (Tables 3 and 4) and the shoot height was significantly affected by both R. clarum and INM inoculation. Similarly, the work of Li et al. (2013) revealed that AM colonization significantly increased plant height.

In both soils, without considering mycorrhizal inoculation, shoot dry weight (SDW) was severely affected by P and $\mathrm{Zn}$ deficiency, and increasing the supply of $\mathrm{P}$ and $\mathrm{Zn}$ significantly enhanced plant growth. With mycorrhizal inoculation, shoot and root dry matter production were markedly increased. For both soils, increasing the rate of P and $\mathrm{Zn}$ application led to a significantly increased seedling SDW. Mycorrhizal species exerted different effects on plant growth; beneficial effects were higher with the $R$. clarum inoculation than with INM inoculation.

In the Sultanönü soil, compared with control plants, mycorrhizal colonization statistically significantly $(\mathrm{P}<0.0001)$ increased the shoot dry weight (SDW) (Tables 3 and 4). R. clarum-inoculated seedlings had a higher SDW than found in the INM inoculation.

For the Konya soil, seedling SDW was less than seedlings grown in the Sultanönü soil. In addition, increasing the rate of $\mathrm{P}$ and $\mathrm{Zn}$ addition also statistically significantly increased seedling SDW (Tables 3 and 4). R. clarum-inoculated seedlings produced higher SDW than INM inoculation. In addition, upon inoculating with indigenous mycorrhizae seedling growth was increased several fold.

In the Konya soil, when seedlings were inoculated with INM, Zn0P0-treated seedlings produced 0.70 g pot $^{-1}$ SDW; however, with the Zn0P1 treatment, the seedlings produced $2.26 \mathrm{~g} \mathrm{pot}^{-1}$ SDW. In both non-inoculated soils, the applica- 
TABLE 3. Significance of P-values (probability) from analysis of variance for different plant parameters.

\begin{tabular}{|c|c|c|c|c|c|c|c|}
\hline Sources & DF & Plant height & Shoot DW & Root DW & Infection (\%) & $\mathrm{P}(\%)$ & $\mathrm{Zn}$ \\
\hline \multicolumn{8}{|l|}{ Sultanönü } \\
\hline Mycorrhizae & 2 & 0.0005 & $<0.0001$ & $<0.0001$ & $<0.0001$ & $<0.0001$ & $<0.0001$ \\
\hline Zinc & 2 & $<0.0001$ & 0.0020 & 0.0035 & 0.0049 & 0.0013 & $<0.0001$ \\
\hline Mycorrhizae $\times$ Zinc & 4 & 0.0506 & 0.4238 & 0.2587 & 0.0073 & 0.2399 & 0.2382 \\
\hline Phosphorus & 1 & 0.0166 & 0.0525 & 0.0546 & 0.7761 & 0.0106 & 0.1909 \\
\hline Mycorrhizae $\times$ Phosphorus & 2 & 0.1085 & 0.8846 & 0.6957 & 0.7935 & 0.7343 & 0.6956 \\
\hline Zinc $\times$ Phosphorus & 2 & 0.0025 & 0.8256 & 0.9489 & 0.4519 & 0.1356 & 0.0085 \\
\hline Mycor. $\times$ Zinc $\times$ Phosphorus & 4 & 0.1151 & 0.5169 & 0.7322 & 0.7958 & 0.9611 & 0.0941 \\
\hline \multicolumn{8}{|l|}{ Konya } \\
\hline Mycorrhizae & 2 & $<0.0001$ & $<0.0001$ & $<0.0001$ & $<0.0001$ & $<0.0001$ & $<0.0001$ \\
\hline Zinc & 2 & $<0.0001$ & $<0.0001$ & $<0.0001$ & 0.2396 & $<0.0001$ & $<0.0001$ \\
\hline Mycorrhizae $\times$ Zinc & 4 & 0.8591 & 0.0008 & 0.0017 & 0.3366 & 0.1367 & 0.0741 \\
\hline Phosphorus & 1 & 0.0038 & 0.0001 & $<0.0001$ & 0.5570 & 0.0480 & 0.5127 \\
\hline Mycorrhizae $\times$ Phosphorus & 2 & 0.8983 & 0.2113 & 0.0241 & 0.7893 & 0.2506 & 0.4047 \\
\hline Zinc $\times$ Phosphorus & 2 & 0.0068 & 0.0217 & 0.0142 & 0.6665 & 0.0452 & 0.0003 \\
\hline Mycor. $\times$ Zinc $\times$ Phosphorus & 4 & 0.0132 & 0.5192 & 0.0115 & 0.8380 & 0.5575 & 0.3981 \\
\hline
\end{tabular}

tion of P significantly increased seedling growth; in addition, increasing the rate of $\mathrm{Zn}$ addition increased seedling growth. In general, there is a negative interaction between $\mathrm{P}$ and $\mathrm{Zn}$ fertilizer application. In the present study, for all inoculated and non-inoculated seedlings, as soils are very poor in both nutrients, it seems that citrus seedlings demand more fertilizer application, especially $\mathrm{P}$ fertilization.

For both soil conditions, not considering inoculation, increasing the addition of $\mathrm{P}$ and $\mathrm{Zn}$ also statistically significantly increased root dry weight (RDW) (Table 3). RDW was also significantly affected by mycorrhizal inoculation. In the Sultanönü soil, $R$. clarum- and INM-inoculated seedlings produced higher RDW than the same treatments using Konya soil. Compared with the Konya soil, indigenous mycorrhizae spores in the Sultanönü soil may be the reason for increased root growth.

\section{Nutrient uptake}

Mycorrhizal inoculation enabled the seedling tissue $\mathrm{P}$ and $\mathrm{Zn}$ concentration to increase nearly two-fold when compared with the non-inoculated plants (Table 5). In accordance with growth data, mycorrhizae inoculation enhanced plant $\mathrm{P}$ and $\mathrm{Zn}$ concentrations, especially under a low rate of $\mathrm{P}$ and $\mathrm{Zn}$ application.

$\mathrm{Zn}$ uptake is very important under $\mathrm{Zn}$ deficient semi-arid soil conditions and in Central Anatolia, the addition of $\mathrm{Zn}$ fertilizer enables increased plant growth. As Zn fertilizer is expensive, it is necessary to use rhizospheric mechanisms, such as mycorrhizae. Similar results were also reported in the same calcareous soils by Ortas (2012a). In our long-term studies, it is clear that mycorrhizal inoculation facilitates the increased uptake of $\mathrm{P}$ and $\mathrm{Zn}$ by citrus plants when exposed to less fertile soil conditions.

Greater effects of mycorrhizal inoculation on P concentration were observed at a higher rate of $\mathrm{P}$ application, and the magnitude of these effects varied in relation to the control depending on the type of inoculation, i.e., R. clarum or INM. Usually, without regarding the inoculation type, the P1-treated seedlings exhibited a higher tissue $\mathrm{P}$ concentration than P0-treated seedlings. Observed benefits in colonized plantlets have often been reported for a high P uptake (Elbon and
Whalen, 2015). In addition, Al-Karaki (2013) reported that citrus growth was insignificantly affected upon the application of a high P fertilizer. It is well known that mycorrhizae are P efficient in P-deficient soils (Smith and Read, 2008).

As can be seen in Table 5, seedlings grown in the Sultanönü soil have a higher tissue P concentration than seedlings grown in the Konya soil. Since soils are less fertile in terms of $\mathrm{P}$, there may be a need to add more P fertilizer for maximum growth and nutrient balance uptake. The results indicate that AMF improves $\mathrm{P}$ efficiency, in particular, at low soil P concentration.

For both soils, mycorrhizal inoculation increased the tissue Zn concentration. For Sultanönü and Konya soils increasing the rate of $\mathrm{Zn}$ addition led to a statistically $(\mathrm{P}<0.0001)$ increased $\mathrm{Zn}$ concentration. Since both soils have an initial Zn concentration less than the critical level, increasing the Zn fertilizer addition naturally increased the seedling tissue Zn concentration. The works of Wu and Zou (2009), Navarro and Morte (2019), Ortas (2012b), Ortas and Ustuner (2014b) indicate that mycorrhizal inoculation significantly enhanced citrus Zn uptake.

Compared with the Sultanönü soil, seedlings grown in the Konya soil had less Zn concentration. Since the Konya soil has a high boron concentration, Zn uptake may have been affected, resulting in limited plant growth. The interaction between the development of naturally occurring mycorrhizal and nutrient uptake requires further elucidation. Since indigenous mycorrhiza inoculation significantly increased P and $\mathrm{Zn}$ concentration of plants grown in Sultanönü soil, it is important to manage indigenous spores under low-input agriculture systems.

\section{$P$ and $\mathrm{Zn}$ increase upon the application of AMF}

The contribution to nutrient increase via mycorrhizae inoculation was also calculated. For both soils, the percentage $\mathrm{P}$ increase in $R$. clarum-inoculated seedlings is higher than INM-inoculated seedlings. In the Konya soil, the P concentration in the shoot of the citrus seedlings in the P0 treatment, when inoculated with $R$. clarum, increased by $83 \%$ and in the P1 treatment by $55 \%$, compared with non-inoculation (Table 6). 
In the same soil, indigenous mycorrhizal inoculation and P0 treatment led to an increase of $78 \%$ and in the P1 treatment the increase was $43 \%$; the Sultanönü soil exhibits a similar trend. Mycorrhizal inoculation significantly improved the $\mathrm{P}$ concentration of the seedlings. In the highest $\mathrm{P}$ application, the shoot $\mathrm{P}$ concentration was comparatively lower. The results were compared with Li et al. (1991a) and they found that under a low $\mathrm{P}$ level application, the mycorrhizal inoculation contribution was $76 \%$ of the total P uptake of white clover plants and $79 \%$ for the high $\mathrm{P}$ level application; they also indicated that nearly all the P uptake was delivered by the mycorrhizae hyphae. In addition, using asparagus plants, Xu et al. (2014) found that mycorrhizal inoculation increased $\mathrm{P}$ concentration by $70 \%$ and an increased $\mathrm{P}$ application reduced the increase in $\mathrm{P}$ concentration. The results show that when input of $P$ fertilizer level increased, the effect of $\mathrm{P}$ fertilizer on $\mathrm{P}$ concentration is decreased.

The seedling Zn concentration increase was calculated and in the Sultanönü soil, the citrus seedlings shoot $\mathrm{Zn}$ concentration in the P0 treatment when inoculated with $R$. clarum increased by $54 \%$ and in the P1 treatment by $43 \%$ compared with non-inoculation. In the same soil, with an indigenous mycorrhizal inoculation, in the P0 treatment, the increase was $57 \%$ and in the P1 treatment it was $41 \%$ compared with non-inoculated seedlings. The contribution of mycorrhizal colonization to the increase in $\mathrm{Zn}$ is usually higher under $\mathrm{P} 0$ treatments than P1 treatments (Table 6). Previously, Kothari et al. (1991) and Li et al. (1991b), using rhizo boxes, calculated the contribution of mycorrhizal hyphae to the $\mathrm{Zn}$ content of clover to be $50 \%$ and $25 \%$ for maize plants; these results concur with data calculated in Table 6.

\section{Mycorrhizal dependency}

Mycorrhizal dependency was calculated for both soils and it was found that increasing the addition of $\mathrm{P}$ significantly reduced MD, especially in the Sultanönü soil.

As seen in Table 7, R. clarum-inoculated seedlings grown in the Sultanönü soil in the P0 treatment, with an increasing $\mathrm{Zn}$ rate,

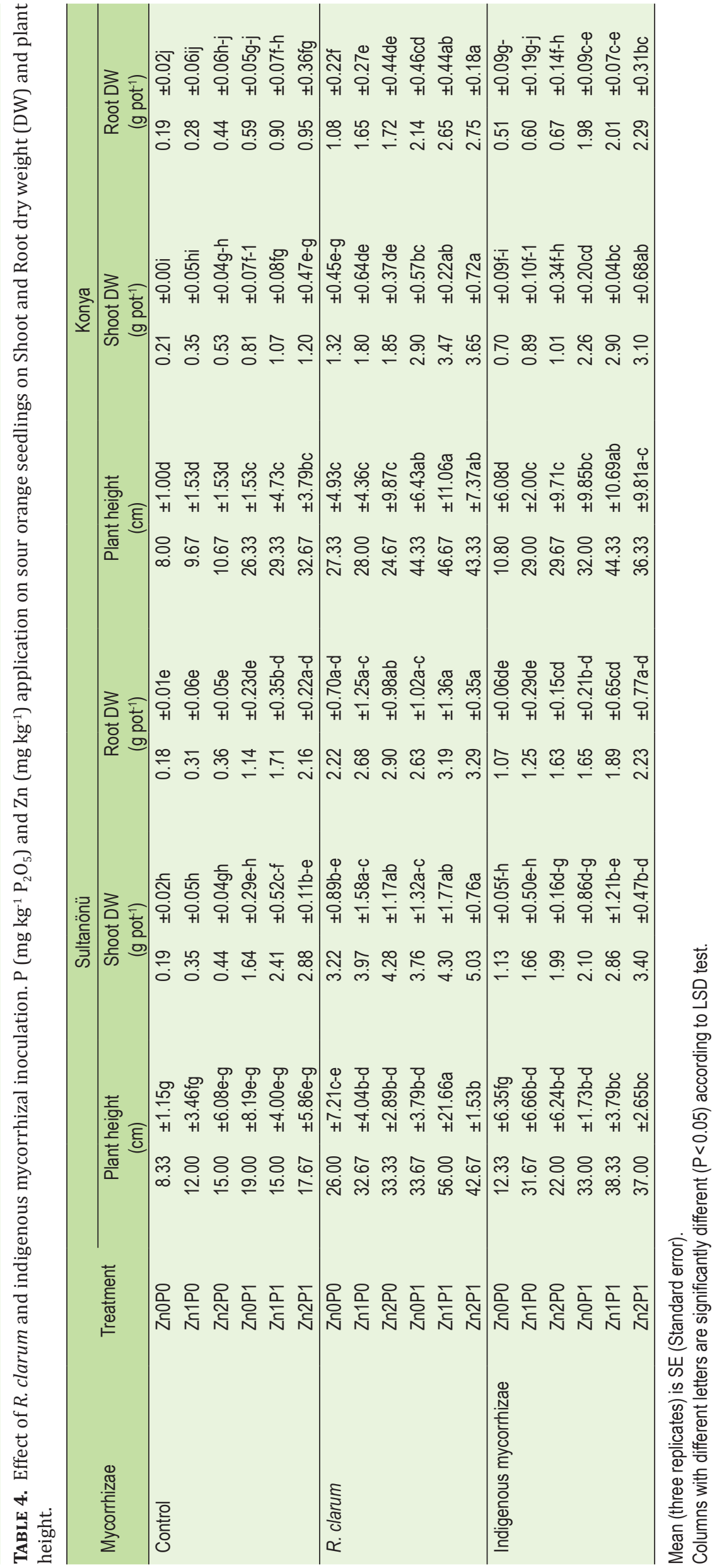


TABLE 5. Effect of $R$. clarum and indigenous mycorrhizal inoculation. $\mathrm{P}\left(\mathrm{mg} \mathrm{kg}^{-1} \mathrm{P}_{2} \mathrm{O}_{5}\right)$ and $\mathrm{Zn}\left(\mathrm{mg} \mathrm{kg}^{-1}\right)$ application on sour orange seedlings shoots $\mathrm{P}$ and $\mathrm{Zn}$ concentration.

\begin{tabular}{|c|c|c|c|c|c|c|c|c|c|}
\hline \multirow{3}{*}{$\begin{array}{l}\text { Mycorrhizae species } \\
\text { Control }\end{array}$} & \multirow{3}{*}{$\begin{array}{l}\text { Treatment } \\
\text { ZnOPO }\end{array}$} & \multicolumn{4}{|c|}{ Sultanönü } & \multicolumn{4}{|c|}{ Konya } \\
\hline & & \multicolumn{2}{|c|}{$\begin{array}{c}\mathrm{P} \\
\left(\mathrm{mg} \mathrm{kg}^{-1}\right)\end{array}$} & \multicolumn{2}{|c|}{$\begin{array}{c}\mathrm{Zn} \\
\left(\mathrm{mg} \mathrm{kg}^{-1}\right) \\
\end{array}$} & \multicolumn{2}{|c|}{$\begin{array}{c}\mathrm{P} \\
\left(\mathrm{mg} \mathrm{kg}^{-1}\right)\end{array}$} & \multicolumn{2}{|c|}{$\begin{array}{c}\mathrm{Zn} \\
\left(\mathrm{mg} \mathrm{kg}^{-1}\right) \\
\end{array}$} \\
\hline & & 0.11 & $\pm 0.02 \mathrm{~g}$ & 15.07 & $\pm 1.22 \mathrm{e}$ & 0.03 & $\pm 0.01 \mathrm{~h}$ & 12.58 & $\pm 0.94 \mathrm{i}$ \\
\hline & Zn1P0 & 0.12 & $\pm 0.01 \mathrm{~g}$ & 17.31 & $\pm 0.30 \mathrm{ee}$ & 0.04 & $\pm 0.02 \mathrm{~h}$ & 15.33 & $\pm 3.06 \mathrm{hi}$ \\
\hline & $\mathrm{Zn} 2 \mathrm{PO}$ & 0.13 & $\pm 0.01 \mathrm{~g}$ & 17.50 & $\pm 3.50 \mathrm{e}$ & 0.04 & $\pm 0.00 \mathrm{~h}$ & 18.97 & $\pm 1.68 \mathrm{e}-\mathrm{i}$ \\
\hline & Zn0P1 & 0.16 & $\pm 0.02 f$ & 16.44 & $\pm 1.39 \mathrm{e}$ & 0.10 & $\pm 0.03 \mathrm{~g}$ & 12.56 & $\pm 2.57 i$ \\
\hline & Zn1P1 & 0.18 & $\pm 0.03 f$ & 24.07 & $\pm 3.11 \mathrm{de}$ & 0.11 & $\pm 0.06 \mathrm{fg}$ & 15.67 & $\pm 1.53 \mathrm{~g}-\mathrm{i}$ \\
\hline & $\mathrm{Zn} 2 \mathrm{P} 1$ & 0.19 & $\pm 0.01 \mathrm{ef}$ & 29.84 & $\pm 7.91 \mathrm{~cd}$ & 0.12 & $\pm 0.01 \mathrm{fg}$ & 17.74 & $\pm 2.53 \mathrm{f}-\mathrm{i}$ \\
\hline \multirow[t]{6}{*}{ R. clarum } & $\mathrm{ZnOPO}$ & 0.23 & $\pm 0.01 \mathrm{de}$ & 32.53 & $\pm 2.40 \mathrm{~b}-\mathrm{d}$ & 0.22 & $\pm 0.01 b$ & 20.77 & $\pm 1.33 \mathrm{e}-\mathrm{i}$ \\
\hline & Zn1P0 & 0.25 & $\pm 0.01 \mathrm{~b}-\mathrm{d}$ & 34.73 & $\pm 2.40 \mathrm{a}-\mathrm{c}$ & 0.21 & $\pm 0.00 \mathrm{~b}$ & 22.62 & $\pm 3.70 \mathrm{e}-\mathrm{h}$ \\
\hline & $\mathrm{Zn} 2 \mathrm{PO}$ & 0.25 & $\pm 0.01 \mathrm{~b}-\mathrm{d}$ & 41.80 & $\pm 1.73 \mathrm{ab}$ & 0.21 & $\pm 0.00 \mathrm{~b}$ & 32.63 & $\pm 5.97 \mathrm{a}-\mathrm{c}$ \\
\hline & Zn0P1 & 0.28 & $\pm 0.04 \mathrm{a}-\mathrm{c}$ & 39.03 & $\pm 3.65 \mathrm{ab}$ & 0.22 & $\pm 0.01 \mathrm{~b}$ & 21.67 & $\pm 1.46 \mathrm{e}-\mathrm{h}$ \\
\hline & Zn1P1 & 0.29 & $\pm 0.01 \mathrm{a}$ & 41.43 & $\pm 2.23 \mathrm{ab}$ & 0.26 & $\pm 0.01 \mathrm{a}$ & 25.27 & $\pm 6.24 c-f$ \\
\hline & $\mathrm{Zn} 2 \mathrm{P} 1$ & 0.28 & $\pm 0.02 \mathrm{ab}$ & 42.60 & $\pm 6.55 \mathrm{a}$ & 0.26 & $\pm 0.02 a$ & 33.87 & $\pm 13.24 \mathrm{ab}$ \\
\hline \multirow[t]{6}{*}{ Indigenous mycorrhizae } & $\mathrm{ZnOP0}$ & 0.22 & $\pm 0.02 \mathrm{de}$ & 26.80 & $\pm 5.09 \mathrm{~cd}$ & 0.15 & $\pm 0.01 \mathrm{ef}$ & 15.02 & $\pm 3.26 \mathrm{~g}-\mathrm{i}$ \\
\hline & $\mathrm{Zn} 1 \mathrm{P0}$ & 0.23 & $\pm 0.01 \mathrm{de}$ & 41.87 & $\pm 3.26 \mathrm{ab}$ & 0.16 & $\pm 0.01 \mathrm{de}$ & 23.67 & $\pm 2.08 \mathrm{~d}-\mathrm{g}$ \\
\hline & $\mathrm{Zn} 2 \mathrm{PO}$ & 0.22 & $\pm 0.03 \mathrm{de}$ & 43.80 & $\pm 7.97 \mathrm{a}$ & 0.17 & $\pm 0.04 \mathrm{c}-\mathrm{e}$ & 26.67 & $\pm 1.60 \mathrm{~b}-\mathrm{e}$ \\
\hline & Zn0P1 & 0.24 & $\pm 0.01 \mathrm{~cd}$ & 34.94 & $\pm 5.28 \mathrm{a}-\mathrm{c}$ & 0.19 & $\pm 0.01 \mathrm{~b}-\mathrm{d}$ & 23.83 & $\pm 3.75 \mathrm{~d}-\mathrm{g}$ \\
\hline & Zn1P1 & 0.25 & $\pm 0.02 a-d$ & 40.00 & $\pm 9.85 \mathrm{ab}$ & 0.20 & $\pm 0.02 \mathrm{cb}$ & 30.77 & $\pm 1.08 \mathrm{a}-\mathrm{d}$ \\
\hline & Zn2P1 & 0.26 & $\pm 0.03 a-d$ & 42.50 & $\pm 6.12 \mathrm{a}$ & 0.20 & $\pm 0.02 b-d$ & 35.03 & $\pm 3.16 \mathrm{a}$ \\
\hline
\end{tabular}

Mean (three replicates) is SE (Standard error).

Columns with different letters are significantly different $(P<0.05)$ according to $L S D$ test.

TABLE 6. Effect of $R$. clarum and indigenous mycorrhizal inoculation. $\mathrm{P}\left(\mathrm{mg} \mathrm{kg}^{-1} \mathrm{P}_{2} \mathrm{O}_{5}\right.$ ) and $\mathrm{Zn}\left(\mathrm{mg} \mathrm{kg}{ }^{-1}\right)$ application on concentration increase (\%) of $\mathrm{P}$ and $\mathrm{Zn}$ in sour orange seedlings.

\begin{tabular}{|c|c|c|c|c|c|c|}
\hline \multirow{3}{*}{ Mycorrhizae species } & \multirow{3}{*}{\multicolumn{2}{|c|}{$\begin{array}{l}\text { P and } \mathrm{Zn} \text { supply } \\
\text { (mg kg-1 soil) }\end{array}$}} & \multicolumn{4}{|c|}{ Concentration increase (\%) } \\
\hline & & & \multicolumn{2}{|c|}{ Sultanönü } & \multicolumn{2}{|c|}{ Konya } \\
\hline & & & $P$ & $\mathrm{Zn}$ & $P$ & $\mathrm{Zn}$ \\
\hline \multirow[t]{8}{*}{ R. clarum } & $\mathrm{Zn0}$ & P0 & 52 & 54 & 85 & 39 \\
\hline & Zn1 & & 50 & 50 & 82 & 32 \\
\hline & $\mathrm{Zn} 2$ & & 50 & 58 & 83 & 42 \\
\hline & & Mean & 51 & 54 & 83 & 38 \\
\hline & $\mathrm{ZnO}$ & P1 & 42 & 58 & 55 & 42 \\
\hline & Zn1 & & 38 & 42 & 57 & 38 \\
\hline & $\mathrm{Zn} 2$ & & 32 & 30 & 54 & 48 \\
\hline & & Mean & 37 & 43 & 55 & 43 \\
\hline \multirow[t]{8}{*}{ Indigenous mycorrhizae } & $\mathrm{ZnO}$ & P0 & 50 & 51 & 77 & 21 \\
\hline & Zn1 & & 45 & 59 & 77 & 35 \\
\hline & $\mathrm{Zn} 2$ & & 48 & 60 & 79 & 29 \\
\hline & & Mean & 48 & 57 & 78 & 29 \\
\hline & $\mathrm{ZnO}$ & P1 & 33 & 53 & 47 & 47 \\
\hline & Zn1 & & 29 & 40 & 43 & 49 \\
\hline & $\mathrm{Zn} 2$ & & 25 & 30 & 39 & 49 \\
\hline & & Mean & 29 & 41 & 43 & 49 \\
\hline
\end{tabular}


TABLE 7. Effect of $R$. clarum and indigenous mycorrhizal inoculation. $\mathrm{P}\left(\mathrm{mg} \mathrm{kg}^{-1} \mathrm{P}_{2} \mathrm{O}_{5}\right)$ and $\mathrm{Zn}\left(\mathrm{mg} \mathrm{kg}^{-1}\right)$ application on sour orange seedlings mycorrhizal dependency (\%).

\begin{tabular}{|c|c|c|c|c|}
\hline \multirow{2}{*}{$\begin{array}{l}\text { Mycorrhizae } \\
\text { species }\end{array}$} & \multirow{2}{*}{\multicolumn{2}{|c|}{$\begin{array}{l}\mathrm{P} \text { and } \mathrm{Zn} \text { supply } \\
\left(\mathrm{mg} \mathrm{kg}^{-1} \text { soil) }\right.\end{array}$}} & \multicolumn{2}{|c|}{ Mycorrhizal dependency (\%) } \\
\hline & & & Sultanönü & Konya \\
\hline \multirow[t]{8}{*}{ R. clarum } & $\mathrm{ZnO}$ & PO & 94 & 84 \\
\hline & $\mathrm{Zn} 1$ & & 91 & 80 \\
\hline & $\mathrm{Zn} 2$ & & 90 & 71 \\
\hline & & Mean & 92 & 79 \\
\hline & Zno & P1 & 56 & 72 \\
\hline & Zn1 & & 44 & 69 \\
\hline & $\mathrm{Zn} 2$ & & 43 & 67 \\
\hline & & Mean & 48 & 69 \\
\hline Indigenous & $\mathrm{ZnO}$ & P0 & 83 & 70 \\
\hline \multirow[t]{7}{*}{ mycorrhizae } & Zn1 & & 79 & 61 \\
\hline & Zn2 & & 78 & 47 \\
\hline & & Mean & 80 & 59 \\
\hline & $\mathrm{ZnO}$ & P1 & 22 & 64 \\
\hline & Zn1 & & 16 & 63 \\
\hline & $\mathrm{Zn} 2$ & & 15 & 61 \\
\hline & & Mean & 18 & 63 \\
\hline
\end{tabular}

increased the MD by 94, 91 and $90 \%$ for $\mathrm{Zn} 0$, Zn1 and Zn2 treatments, respectively. Upon the addition of $100 \mathrm{mg} \mathrm{kg}^{-1}$ $\mathrm{P}_{2} \mathrm{O}_{5}$, the MD decreased by 56,44 and $43 \%$ respectively. For the INM inoculation, without the application of $\mathrm{P}$ and with an increasing $\mathrm{Zn}$ rate, the MD increase was 83, 79 and 78\% for $\mathrm{Zn} 0, \mathrm{Zn} 1$ and $\mathrm{Zn} 2$ treatments, respectively. With the 100 mg kg-1 $\mathrm{P}_{2} \mathrm{O}_{5}$ addition, the MD was decreased by 22, 16 and $15 \%$ respectively. Xu et al. (2014) indicated that mycorrhizal dependency significantly decreased with increasing soil $\mathrm{P}$ concentration in mycorrhizal-inoculated asparagus plants.

It seems that upon the addition of low $\mathrm{P}$ fertilizer mycorrhizal dependency is more affected by the addition of P fertilizer than Zn fertilizer; this finding is parallel to our previous findings. In several of our previous works on citrus plants, the MD mostly depended upon $\mathrm{P}$ requirement and less for $\mathrm{Zn}$ (Ortas and Akpinar, 2006; Ortas et al., 2016).

In our previous experiments we found that although mycorrhizal inoculation increased plant $\mathrm{Zn}$ uptake, the plants were found to be much more mycorrhizal dependent on $\mathrm{P}$ nutrition (Ortas, 2012a; Ortas and Akpinar, 2006).

In the Konya soil, increasing the addition of P slightly reduced MD. In general, upon the addition of high P, the MD was reduced; however, for the Konya soil the applied P level may not be limiting mycorrhizal development and plant growth parameters. In the Konya soil, increasing the rate of $\mathrm{P}$ and $\mathrm{Zn}$ addition slightly reduced MD. In the P0 treatment, with $R$. clarum inoculation, the MD was 84,80 and $71 \%$ for $\mathrm{Zn} 0, \mathrm{Zn} 1$ and $\mathrm{Zn} 2$ treatments, respectively. With the addition of $100 \mathrm{mg} \mathrm{kg}^{-1} \mathrm{P}_{2} \mathrm{O}_{5}$, the MD was 72, 69 and 67\%. For INM inoculation, without $\mathrm{P}$ application, the MD was 70, 61 and $47 \%$ for the $\mathrm{Zn} 0, \mathrm{Zn} 1$ and Zn2 treatments, respectively. With the addition of $100 \mathrm{mg} \mathrm{kg}^{-1} \mathrm{P}_{2} \mathrm{O}_{5}$, the MD was 64,63 and $61 \%$, respectively.

It seems that in the P0 treated soil, increasing the $\mathrm{Zn}$ fertilizer rate decreased MD, however, upon the addition of $\mathrm{P}$ treatment, the MD did not change upon the application of Zn fertilizer. The results obtained in Table 6 show that citrus seedlings are highly mycorrhizal dependent under low $\mathrm{P}$ and Zn supply, and therefore inoculation of mycorrhizae in soil with $\mathrm{P}$ and $\mathrm{Zn}$ deficiency is a critical factor in crop production and $\mathrm{P}$ and $\mathrm{Zn}$ uptake. So far, all the experiments conducted have shown that the benefits of mycorrhizal fungi varied according to fungal isolates and plant species. In the present study it seems that MD also depend on soil types. Also the contribution of INM on dependency is very divers in term of soil types.

\section{Conclusion}

Based on our results, it can be concluded that the inoculation of exotic $R$. clarum and INM with the addition of $\mathrm{P}$ and $\mathrm{Zn}$ fertilizer significantly increased the growth of citrus seedlings; hence the management of indigenous mycorrhizae may be an important mycorrhizal source for better plant growth. Indigenous mycorrhizae spore management is very important, especially for long-term agricultural productivity and soil quality.

Increasing the addition of P and Zn fertilizer significantly increased the seedling growth; in addition, mycorrhizal inoculation increased the yield many fold. Mycorrhizal inoculated plants under the P0 treatment exhibited an up to 83\% increase of $\mathrm{P}$ concentration and upon increasing the $\mathrm{P}$ level the contribution decreased. Under low P application, with mycorrhizal inoculation, increasing the Zn level application resulted in an increased plant $\mathrm{Zn}$ concentration.

The results obtained indicate that sour orange is a highly MD plant and mycorrhizae play an essential role in the $\mathrm{P}$ and $\mathrm{Zn}$ nutrition of plants in P- and Zn-deficient soils. In the Konya soil, in the P0 treated soil, the MD reduction was significantly affected by increasing the addition of $\mathrm{Zn}$; however, in P1 treated soils, the MD was only slightly affected. The results partially support our hypothesis; however, this hypothesis needs to be retested for indigenous mycorrhizae.

\section{Acknowledgments}

Thanks to TUBITAK TOGTAG-3330 project for financial support.

\section{References}

Al-Karaki, G.N. (2013). The effect of arbuscular mycorrhizal fungi on the establishment of sour orange (Citrus aurantium) under different levels of phosphorus. Acta Hortic. 984, 103-108. https:// doi.org/10.17660/ActaHortic.2013.984.8.

Elbon, A., and Whalen, J.K. (2015). Phosphorus supply to vegetable crops from arbuscular mycorrhizal fungi: A review. Biological Agric. Hortic. 31, 73-90. https://doi.org/10.1080/01448765.2014.966147.

Giovannetti, G., and Mosse, B. (1980). An evaluation of techniques for measuring vesicular-arbuscular mycorrhiza in roots. New Phytologist 84, 489-500. https://doi.org/10.1111/j.1469-8137.1980. tb04556.x.

Koske, R.E., and Gemma, J.N. (1989). A modified procedure for staining roots to detect VA-mycorrhizas. Mycol. Res. 92, 486-488. https://doi.org/10.1016/S0953-7562(89)80195-9.

Kothari, S.K., Marschner, H., and Romheld, V. (1991). Contribution of the VA mycorrhizal hyphae in acquisition of phosphorus and zinc by maize grown in a calcareous soil. Plant and Soil 131, 177-185. https://doi.org/10.1007/BF00009447.

Li, X.L., George, E., and Marschner, H. (1991a). Extension of the phosphorus depletion zone in VA-mycorrhizal white clover in a calcareous soil. Plant and Soil 136, 41-48. https://doi.org/10.1007/ BF02465218.

Li, X.L., Marschner, H., and George, E. (1991b). Acquisition of phosphorus and copper by VA-mycorrhizal hyphae and root-to- 
shoot transport inwhite clover. Plant and Soil 136, 49-57. https:// doi.org/10.1007/BF02465219.

Li, Y., Zou, Y.N., and Wu, Q.S. (2013). Effects of Diversispora spurca inoculation on growth, root system architecture and chlorophyll contents of four Citrus genotypes. Int. J. Agric. Biol. 15, 342-346.

Murphy, Y., and Riley, J.P.A. (1962). Modified single solution method for determination of phosphate in natural waters. Anal. Chem. Acta 27, 31-36. https://doi.org/10.1016/S0003-2670(00)88444-5.

Navarro, J.M., and Morte, A. (2019). Mycorrhizal effectiveness in Citrus macrophylla at low phosphorus fertilization. J. Plant Physiol. 232, 301-310. https://doi.org/10.1016/j.jplph.2018.11.027.

Nunes, M.D., Soares, A.C.F., Soares, W.D., and Ledo, C.A.D. (2006). Natural mycorrhizal colonization of citrus rootstocks under field conditions. Pesquisa Agropec. Brasil. 41, 525-528. https://doi. org/10.1590/S0100-204X2006000300021.

Ortas, I. (2008). Field trials on mycorrhizal inoculation in the Eastern Mediterranean Horticultural Region. In Mycorrhiza Works, F. Feldmann, Y. Kapulnık, and J. Baar, eds. (Hannover, Germany), p. 56-77.

Ortas, I. (2012a). Do maize and pepper plants depend on mycorrhizae in terms of phosphorus and zinc uptake? J. Plant Nutr. 35, 16391656. https://doi.org/10.1080/01904167.2012.698346.

Ortas, I. (2012b). Mycorrhiza in Citrus: growth and nutrition. In Advances in Citrus Nutrition, A.K. Srivastava, ed. (The Netherlands: Springer-Verlag). https://doi.org/10.1007/978-94-007-4171-3_23.

Ortas, I. (2017). Effect of mycorrhizal inoculation on P and Zn uptake in Citrus (Citrus spp.). Current Hortic. 5, 59-60.

Ortas, I., and Akpinar, C. (2006). Response of kidney bean to arbuscular mycorrhizal inoculation and mycorrhizal dependency in $\mathrm{P}$ and $\mathrm{Zn}$ deficient soils. Acta Agric. Scandinavica, Section B - Soil and Plant Sci. 56, 101-109. https://doi.org/10.1080/09064710510029196.

Ortas, I., and Varma, A. (2007). Field trials of bioinoculants. In Modern Tools and Techniques, R. Oelmüller, and A. Varma, eds. (Springer-Verlag), p. 397-413. https://doi.org/10.1007/978-3-54070865-0_26.

Ortas, I., and Ustuner, O. (2014a). Determination of different growth media and various mycorrhizae species on citrus growth and nutrient uptake. Sci. Hortic. 166, 84-90. https://doi.org/10.1016/j. scienta.2013.12.014.

Ortas, I., and Ustuner, O. (2014b). The effects of single species, dual species and indigenous mycorrhiza inoculation on citrus growth and nutrient uptake. Europ. J. Soil Biol. 63, 64-69. https://doi. org/10.1016/j.ejsobi.2014.05.007.

Ortas, I., and Coskan, A. (2016). Precipitation as the most affecting factor on soil-plant environment conditions affects the mycorrhizal spore numbers in three different ecological zones in Turkey. Acta Agric. Scandinavica, Section B - Soil and Plant Sci. 66, 369-378. https://doi.org/10.1080/09064710.2015.1132005.

Ortas, I., Akpinar, C., and Demirbas, A. (2016). Sour orange (Citrus aurantium $\mathrm{L}$.) growth is strongly mycorrhizal dependent in terms of phosphorus (P) nutrition rather than zinc (Zn). Commun. Soil Sci. Plant Anal. 47, 2514-2527. https://doi.org/10.1080/00103624.20 16.1254792 .

Ortas, I., Demirbas, A., and Akpinar, C. (2018). Under sterilized and non-sterilized soil conditions, mycorrhizal dependency in citrus plants depends on phosphorus fertilization rather than zinc application. Eur. J. Hortic. Sci. 83, 81-87. https://doi.org/10.17660/ eJHS.2018/83.2.3.

Plenchette, C., Fortin, J.A., and Furlan, V. (1983). Growth-responses of several plant-species to mycorrhizae in a soil of moderate P-fertility 1. Mycorrhizal dependency under field conditions. Plant and Soil 70, 199-209. https://doi.org/10.1007/BF02374780.
Rouphael, Y., Franken, P., Schneider, C., Schwarz, D., Giovannetti, M., Agnolucci, M., De Pascale, S., Bonini, P., and Colla, G. (2015). Arbuscular mycorrhizal fungi act as biostimulants in horticultural crops. Sci. Hortic. 196, 91-108. https://doi.org/10.1016/j. scienta.2015.09.002.

Satir, N.Y., Ortas, I., and Satir, O. (2016). The influence of mycorrhizal species on sour orange (Citrus aurantium L.) growth under saline soil conditions. Pakistan J. Agric. Sci. 53, 399-406. https://doi. org/10.21162/PAKJAS/16.2425

Smith, S.E., and Read, D.J. (2008). Mycorrhizal Symbiosis (San Diego, CA: Academic Press)

Wu, Q.S., and Zou, Y.N. (2009). Mycorrhizal influence on nutrient uptake of citrus exposed to drought stress. Philippine Agric. Scientist 92, 33-38.

Wu, Q., Xia, R., and Zou, Y. (2006). Arbuscular mycorrhizal fungal growth on citrus roots and its correlations with soil available phosphorus content and phosphatase activity. Yingyong Shengtai Xuebao 17, 685-689.

Wu, Q.S., Zou, Y.N., and Wang, G.Y. (2011). Arbuscular mycorrhizal fungi and acclimatization of micropropagated citrus. Commun. Soil Sci. Plant Anal. 42, 1825-1832. https://doi.org/10.1080/00103624 .2011.587570.

Wu, Q.S., Srivastava, A.K., and Zou, Y.N. (2013). AMF-induced tolerance to drought stress in citrus: A review. Sci. Hortic. 164, 7787. https://doi.org/10.1016/j.scienta.2013.09.010.

Wu, Q.S., Srivastava, A.K., Zou, Y.N., and Malhotra, S.K. (2017a). Mycorrhizas in citrus: Beyond soil fertility and plant nutrition. Indian J. Agric. Sci. 87, 427-443.

Wu, Q.S., Sun, P., and Srivastava, A.K. (2017b). AMF diversity in citrus rhizosphere. Indian J. Agric. Sci. 87, 653-656.

Xu, P., Liang, L.Z., Dong, X.Y., Xu, J., Jiang, P.K., and Shen, R.F. (2014). Response of soil phosphorus required for maximum growth of Asparagus officinalis L. to inoculation of arbuscular mycorrhizal fungi. Pedosphere 24, 776-782. https://doi.org/10.1016/S10020160(14)60064-3.

Received: Oct. 20, 2017

Accepted: Jan. 29, 2019

Address of author:

Ibrahim Ortas

Department of Soil Science and Plant Nutrition, University of Cukurova, Faculty of Agriculture, Adana, Turkey E-mail: iortas@cu.edu.tr; Tel. and Fax:+90 3223386643 